\title{
ANALISIS PERLAKUAN AKUNTANSI DAN PELAPORAN PERTANGGUNGJAWABAN SOSIAL PADA PT. ANGKASA PURA I (PERSERO) CABANG BANDAR UDARA INTERNASIONAL SAM RATULANGI MANADO
}

\author{
Tumilantouw Frety Emma Belda ${ }^{1}$, Hendrik Manossoh², Sintje Rondonuwu ${ }^{3}$ \\ ${ }^{1,2,3}$ Fakultas Ekonomi dan Bisnis, Jurusan Akuntansi. Universitas Sam Ratulangi, Jl. Kampus Bahu Manado, \\ 95115, Indonesia \\ E-mail :tumilantouwfrety@gmail.com
}

\begin{abstract}
Companies need a response that positively by public because the comunnity constitutes one of the elements that can determine success business an entity. Accounting social responsibility is very powerful tool for the company in expressing social activities. The purpose of this study is to find out how accounting treatment and reporting corporate social responsibility in accordance with UU. No. 40 Tahun 2007, Peraturan Menteri BUMN No. 5/MBU/2007 and financial accounting standards. Data collection methods in this study are interviews and document review. Data analysis method of this research is Miles and Huberman, which compares the company's procedures with existing theories. The result shows that the accounting treatment and reporting in PT. Angkasa Pura I (Persero) has basically been fitted with financial accounting standards, UU No. 40 Tahun 2007, and Peraturan Menteri BUMN No.5/MBU/2007, but a company should make separate reports about the realization of activities to ease evaluate program that will be implemented.
\end{abstract}

Keywords: accounting treatment, corporate social responsibility, partnerships and community development program

\section{PENDAHULUAN}

Suatu perusahaan yang berdiri tentunya memiliki suatu tujuan atas kegiatan yang di lakukannya baik menghasilkan maupun menguntungkan sebagai suatu bentuk pelayanan publik. Pada perkembangannya saat ini banyak perusahaan yang hanya berfokus pada kegiatan operasi semata demi menghasilkan keuntungan yang besar dan bentuk akuntabilitas finansial demi memenuhi kebutuhan informasi stakeholder perusahaan tersebut. Dalam menjalankan usahanya, suatu entitas tidak terlepas dari masyarakat dan lingkungan sekitarnya, sehingga menciptakan hubungan timbal balik antara masyarakat dan perusahaan.

Maraknya isu kedermawanan sosial perusahaan belakangan ini mengalami perkembangan yang sangat pesat dan sejalan dengan berkembangnya konsep tanggung jawab sosial perusahaan, dimana perusahaan ikut dalam berpartisipasi dan berempati terhadap berbagai masalah lingkungan dan sosial sekitar perusahaan. Corporate Social Responsibility (CSR) merupakan suatu konsep akuntansi yang dapat membawa perusahaan agar melaksanakan tanggungjawabnya terhadap lingkungan dan masyarakat.

Praktik dan pengungkapan tanggungjawab sosial perusahaan merupakan konsekuensi logis dari implementasi konsep Corporate Goverence, yang menyatakan bahwa perusahaan perlu memperhatikan kepentingan stakeholdersnya sesuai dengan aturan yang ada dan menjalin kerja sama yang aktif dengan stakeholder demi kelangsungan hidup jangka panjang perusahaan. (Susanto, 2013). Akuntansi pertanggungjawaban sosial merupakan alat yang sangat berguna bagi perusahaan dalam mengungkapkan aktivitas sosialnya. Seperti yang disebutkan dalam PSAK No. 1 paragraf ke 12 (Revisi 2009) bahwa suatu entitas dapat pula menyajikan laporan mengenai lingkungan hidup dan laporan nilai tambah yang terpisah dari laporan keuangan utama. 
Undang-Undang No. 40/2007, Perseroan Terbatas Pasal 74 ini mewajibkan perseroan untuk melaksanakan tanggung jawab sosial dan lingkungan dan wajib melaporkan pelaksanaan tanggung jawab tersebut di laporan tahunan. Selain itu Peraturan Menteri BUMN No. Per-05/MBU/2007 menyatakan maksud dan tujuan pendirian BUMN tidak hanya mengejar keuntungan melainkan turut aktif memberikan bimbingan dan bantuan kepada pengusaha golongan ekonomi lemah, koperasi dan masyarakat. Berdasarkan uraian latar belakang diatas, maka rumusan masalah dalam penelitian ini adalah :

1. Apakah PT. Angkasa Pura I (Persero) telah melaporkan tanggung jawab sosialnya sesuai dengan Undang-Undang No. 40 tahun 2007 - Perseroan Terbatas pasal 74 tentang Tanggung Jawab Sosial dan Lingkungan dan Peraturan Menteri BUMN No. 5/MBU/2007 tentang Program Kemitraan dan Bina Lingkungan?

2. Apakah PT. Angkasa Pura I (Persero) menyajikan laporan mengenai tanggung jawab sosial di luar laporan keuangan utama seperti yang disebutkan dalam PSAK No.1 Paragraf 12 Revisi 2009 tentang Entitas dapat pula menyajikan, terpisah dari laporan keuangan, laporan mengenai lingkungan hidup dan laporan nilai tambah (value added statement)?

Berdasarkan rumusan masalah yang ada, tujuan dilakukannya penelitian ini adalah untuk mengetahui:

1. Untuk menganalisis apakah PT. Angkasa Pura I (Persero) telah melaporkan tanggung jawab sosialnya sesuai dengan Undang-Undang No. 40 tahun 2007 - Perseroan Terbatas pasal 74 tentang Tanggung Jawab Sosial Lingkungan dan Peraturan Menteri BUMN No. 5/MBU/2007 tentang Program Kemitraan dan Bina Lingkungan.

2. Untuk menganalisis apakah PT. Angkasa Pura I (Persero) Sulawesi Utara, menyajikan laporan mengenai tanggung jawab sosial diluar laporan keuangan utama seperti yang disebutkan dalam PSAK No.1 Paragraf 12 Revisi 2009.

\section{TINJAUAN PUSTAKA}

\subsection{Pengertian Akuntansi}

Akuntansi dapat didefinisikan sebagai suatu proses identifikasi, pengukuran, dan pengkomunikasian informasi ekonomi yang menghasilkan informasi yang berguna bagi pembuatan kebijakan dan keputusan oleh pemakainya (Samryn, 2012: 4). Menurut Weygandt, Kimmel, dan Kieso (2012: 4) "Accounting is an information system that identifies, records, and communicates the economic events of an organization to interest users." Artinya akuntansi adalah suatu sistem informasi yang mengidentifikasi, mencatat dan mengkomunikasikan peristiwa-peristiwa ekonomi dari suatu organisasi kepada para pengguna yang berkepentingan.

\subsection{Akuntansi Manajemen}

Salman \& Farid (2016: 2-4) Akuntansi manajemen adalah pengelugmbangan dan penerapan berbagai teknik pencatatan (recording), analisis, interpretasi dan presentasi, membuat perhitungan keuangan, perhitungan biaya, dan data lain yang aktif dan efektif dalam menjalankan fungsi kinerja manajerial, yaitu, perencanaan, pengambilan keputusan dan pengendalian. Akuntansi manajemen diharapkan dapat membantu manajemen dalam proses pengambilan keputusan agar keputusan-keputusan ekonomi yang dikuasainya atau kekayaan perusahaan dapat dialokasikan dan ditransformasikan secara lebih efektif serta efisien.

\subsection{Tanggung Jawab Sosial Perusahaan (Corporate Social Responsibility) \\ 2.3.1 Konsep Tanggungjawab Sosial Perusahaan}

"The continuing by businesses to behave ethically and contribute to economic development while improving the quality of life of the workforce and their families as well as the local community and society at large." (Abdala, et al. 2014). Dari pengertian ini, WBCSD menyimpulkan bahwa CSR adalah sebuah komitmen yang berkelanjutan dari 
sebuah bisnis untuk berperilaku sesuai etik dan berkontribusi terhadap perkembangan ekonomi selagi meningkatkan kualitas kehidupan dari tenaga kerjanya dan keluarga beserta komunitas lokal dan seluruh masyarakat.

\subsubsection{Manfaat Corporate Social Responsibility}

"Corporate Social Responsibility program as to encourage the positive contributions that multinational enterprises can make to economics, environmental and social progress and to minimize the difficulties to which their various operations may give rise." (Homayoun, et al. 2015).

\subsubsection{Corporate Social Responsibility sebagai Kebijakan}

"As well as the importance of social responsibility in this era of information technology, privatization and knowledge based economies that restructured the economy with the increasing importance of intangible assets (intellectual property) and its effect on market value." (Shoubaki, et al. 2013). Demikian juga dengan pentingnya tanggungjawab sosial diera privasi informasi teknologi ini dan pengetahuan dasar ekonomi yang menyesuaikan dengan semakin pentingnya intangible assets dan efeknya terhadap nilai pasar.

\subsubsection{Pengukuran Biaya Corporate Social Responsibility}

1. Penilaian pengganti (surrogate valuation)

2. Teknik survey (survey techniques)

3. Biaya perbaikan dan pencegahan (restoration or avoidance cost)

4. Penilaian (appraisal)

5. Putusan pengadilan (court decisions)

\subsection{Akuntansi Pertanggungjawaban Sosial}

\subsubsection{Definisi Akuntansi Pertanggungjawaban Sosial}

"Some studies argue that CSR activities might be consistent with wealth maximization motives of the firm and provide appropriate information for corporate decision making. There is a natural link between CSR and accounting because the accounting profession has a general responsibility for measurement, disclosure and assurance of information including CSR-related information." (Bayoud, et al. 2012).

\subsubsection{Indikator Penyajian Informasi dalam Laporan Keberlanjutan (Sustainability Report)}

Laporan keberlanjutan (sustainability report) adalah laporan yang diterbitkan oleh perusahaan atau organisasi mengenai dampak ekonomi, lingkungan dan sosial yang disebabkan oleh aktivitas sehari-harinya. Laporan keberlanjutan juga menyajikan nilai-nilai dan model tata kelola organisasi dan menunjukkan kaitan antara strategi dan komitmennya terhadap ekonomi global yang berkelanjutan.

\subsubsection{Pelaporan Akuntansi Pertanggungjawaban Sosial}

Laporan tanggungjawab sosial merupakan aktivitas tanggungjawab sosial yang telah dilakukan perusahaan baik berkaitan dengan permasalahan dampak sosial maupun lingkungan. Laporan tersebut menjadi bagian yang tidak terpisahkan dengan laooran tahunan (anuual report) yang dipertanggungjawabkan direksi didepan sidang Rapat Umum Pemegang Saham (RUPS). Laporan ini berisi laporan program-program sosial dan lingkungan perseroan yang dilakukan selama tahun terakhir (Nur, 2012).

\subsubsection{Pelaporan Pertanggungjawaban Sosial Badan Usaha Milik Negara (BUMN)}

PT. Angkasa Pura I (Persero) selain sebagai perseroan yang bergerak dibidang jasa di Indonesia juga merupakan salah satu BUMN (badan usaha milik negara). Dalam Peraturan Menteri BUMN No. 05/MBU/2007 tentang Program Kemitraan dan Bina Lingkungan (PKBL) disebutkan bahwa maksud dan tujuan pendirian BUMN tidak hanya mengejar keuntungan melainkan turut aktif memberikan bimbingan dan bantuan kepada pengusaha golongan ekonomi lemah, koperasi dan masyarakat. Sehingga hal ini mengharuskan PT. Angkasa Pura I (Persero) melakukan tanggung jawab sosial serta melaporkannya. 


\subsection{Penelitian Terdahulu}

1. Maria Wijaya (2012) dalam penelitian yang berjudul Faktor-faktor Yang Mempengaruhi Pengungkapan Tanggungjawab Sosial Pada Perusahaan Manufaktur Yang Terdapat Di Bursa Efek Indonesia. Tujuan dari penelitian ini adalah Untuk memperoleh bukti empiris adanya pengaruh factor ukuran perusahaan, profitabilitas, ukuran dewan komisaris, leverage, kinerja perusahaan terhadap pengungkapa tanggung jawab sosial. Hasil dari penelitian ini menunjukan Ukuran dewan komisaris, leverage, ukuran perusahaan, profitabilitas tidak berpengaruh signifikan terhadap pengungkapan tanggung jawab sosial. Sedangkan Ukuran perusahaan berpengaruh.

2. Abdul Ghofur (2016) dalam penelitian yang berjudul Perlakuan Akuntansi dan Pelaporan Pertanggungjawaban Sosial Perusahaan PT. PLN (Persero) P3BJB APP Surabaya. Tujuan dari penelitian ini adalah Untuk mengetahui apakah PT. PLN (Persero) P3BJB APP Surabaya telah melaporkan tanggungjawab sosialnya sesuai UU No. 40 Tahun 2007 Perseroan Terbatas Pasal 74 tentang Tanggung Jawab Sosial dan Lingkungan. Hasil penelitian ini menunjukan Penerapan program CSR PT. PLN (Persero) P3BJB APP Surabaya telah mematuhi bentuk kepatuan perseroan dalam memenuhi UU. No. 40 tahun 2007.

\section{METODE PENELITIAN}

\subsection{Jenis Penelitian}

Jenis penelitian ini adalah penelitian kualitatif dimana penulis menganalisis perlakuan akuntansi terhadap pelaporan pertanggungjawaban sosial di salah satu BUMN. Penelitian ini memiliki kesesuaian dengan fokus penelitian, dimana penulis mengharapkan untuk dapat memperoleh gambaran yang jelas dan mendalam tentang perlakuan akuntansi dan pelaporan pertanggungjawaban sosial pada PT. Angkasa Pura I (Persero) Cabang Bandar Udara Internasional Sam Ratulangi Manado.

\subsubsection{Sumber Data}

Data yang digunakan dalam penelitan ini yaitu data primer yang diperoleh secara langsung melalui wawancara dengan pihak PT. Angkasa Pura I (Persero) Cabang Bandar Udara Internasional Sam Ratulangi Manado. Dan data sekunder melalui data sejarah perusahaan, bidang usaha, data program CSR yang telah diimplementasikan oleh PT. Angkasa Pura I (Persero) Cabang Bandar Udara Internasional Sam Ratulangi Manado.

\subsection{Tempat dan Waktu Penelitian}

Penelitian ini dilaksanakan di PT. Angkasa Pura I (Persero) Cabang Manado Jl. AA. Maramis, Lapangan Mapanget Manado. Waktu Penelitian dimulai pada bulan Maret 2017 sampai dengan Mei 2017.

\subsection{Prosedur Penelitian}

Pemilihan Judul. Permohonan Izin Penyusunan, Melakukan Penelitian, Membuat Draft Proposal, Diskusi Draft Proposal, Membuat Proposal, Diskusi Proposal, Konsultasi Proposal, Perubahan Proposal, Melaksanakan Penelitian, Menentukan Informan, Wawancara dengan Informan, Mengelola Data dari Hasil Penelitian, Menarik Kesimpulan, Menulis Skripsi, Konsultasi Skripsi, Melakukan Perbaikan, dan Seminar Skripsi.

\subsection{Metode Pengumpulan Data}

Penelitian ini dilakukan dengan mengumpulkan data-data berdasarkan pada teknik pengumpulan data sebagai berikut :

1. Wawancara

Kegiatan wawancara dilakukan dengan mengajukan pertanyaan kepada responden, yaitu kepada pihak PT. Angkasa Pura I (Persero) Manado.

2. Dokumentasi 
Pengumpulan data dilakukan dengan mengumpulkan data melalui dokumen dan berkas yang berhubungan dengan penelitian, yaitu meliputi :

1) Laporan Program Kemitraan dan Bina Lingkungan

2) Laporan Keuangan Perusahaan

3) Laporan Keberlanjutan Perusahaan

\subsection{Metode Analisis Data}

Menurut Miles dan Huberman (Sugiyono, 2016:91) analisis data dilakukan selama pengumpulan data di lapangan dan setelah semua data terkumpul dengan teknik analisis model interaktif. Analisis ini berlangsung secara bersama-sama dengan proses pengumpulan data dengan alur tahapan sebagai berikut.

1. Reduksi Data

2. Penyajian Data

3. Penyimpulan dan Verifikasi Kesimpulan Akhir

\section{HASIL PENELITIAN DAN PEMBAHASAN}

\subsection{Gambaran Umum Perusahaan}

\subsubsection{Sejarah Singkat PT. Angkasa Pura}

Bandar Udara Sam Ratulangi pada awalnya dibangun oleh Jepang pada tahun 1942 dengan panjang Runway 700 Meter dan lebar 23 Meter serta diberi nama Lapangan Udara Mapanget. Kemudian ketika terjadi Pergolakan Pergerakan Rakyat Semesta (PERMESTA), pasukan Tentara Pusat menamakan bandara ini sebagai Lapangan Udara Tugiman untuk mengenang seorang tentara mereka Sersan Mayor Tugiman yang wafat ketika pertempuran terjadi di Mapanget. Kemudian bandara ini kembali dinamakan Lapangan Udara Mapanget karena keberadaannya kala itu di Wanua Mapanget, Onderdistik Tatelu. Seiring perjalanan waktu, terjadi lagi perubahan penyebutan bandara ini menjadi Lapangan Udara A. A. Maramis, yang sekaligus digunakan sebagai nama jalan raya dari arah Manado ke bandara. Akhirnya, untuk mengenang Pahlawan Nasional Indonesia yang berasal dari Minahasa Sulawesi Utara (Sulut) yaitu Dr. Gerungan Saul Samuel Jacob Ratulangi, bandara ini oleh pemerintah dinamakan Lapangan Udara Sam Ratulangi yang kemudian dikenal hingga saat ini sebagai Bandar Udara Sam Ratulangi Manado.

\subsection{Hasil Penelitian}

\subsubsection{Laporan Program Kemitraan \& Bina Lingkungan (PKBL) PT. Angkasa Pura I (Persero)}

Laporan Program Kemitraan dan Bina Lingkungan (PKBL) ini disusun terpisah dari laporan keuangan utama perusahaan sebagai bentuk pelaksanaan Undang-Undang No. 19 tahun 2003 tentang Badan Usaha Milik Negara. Dalam penyusunan laporan Program Kemitraan dan Bina Lingkungan (PKBL) PT. Angkasa Pura I (Persero) menggunakan dasar Surat Edaran Menteri BUMN No. SE-02/MBU/Wk/2012 tentang Penetapan Pedoman Akuntansi Program Kemitraan dan Bina Lingkungan (PKBL) Revisi tahun 2012. Penyusunan laporan keuangan tersebut menggunakan dasar Standar Akuntansi Keuangan Entitas Tanpa Akuntabilitas Publik (SAK ETAP) dan Pernyataan Standar Akuntansi Keuangan 45 (Revisi 2011) tentang Pelaporan Keuangan Entitas Nirlaba. Basis akuntansi yang digunakan adalah dasar akrual (accrual basis) sehingga aset, liabilitas, pendapatan dan beban diakui pada saat terjadinya. Jadi, pencatatan harus dilakukan ketika suatu transaksi terjadi walaupun penerimaan atau pengeluaran kas atau setara kas belum dilakukan oleh unit PKBL. Beban segera diakui dalam Laporan Aktivitas jika pengeluaran tidak menghasilkan manfaat ekonomi masa depan. Dasar pengukuran yang digunakan adalah biaya historis dan nilai wajar. Dalam biaya historis, aset adalah jumlah kas atau setara kas yang dibayarkan atau nilai wajar dari pembayaran yang diberikan untuk memperolehnya. Sedangkan kewajiban dicatat sebesar kas atau setara kas yang diterima atau sebesar nilai wajar dari aset non-kas yang 
diterima sebagai penukar dari kewajiban pada saat terjadinya kewajiban. Nilai wajar adalah jumlah yang dipakai untuk mempertukarkan suatu aset, atau untuk menyelesaikan suatu kewajiban, antara pihak-pihak yang berkeinginan dan memiliki pengetahuan memadai dalam suatu transaksi dengan wajar.

Berdasarkan Surat Edaran Menteri BUMN No. SE-02/MBU/Wk/2012 tentang Penetapan Pedoman Akuntansi Program Kemitraan dan Bina Lingkungan (PKBL) penyusunan Laporan Program Kemitraan dan Bina Lingkungan digunakan beberapa prinsip yaitu:

1. Prinsip Periodisitas (Accounting Period)

Prinsip ini menghendaki pembagian transaksi dan penyusunan Laporan Keuangan dalam periode-periode pelaporan. Hal ini untuk memudahkan pengukuran kinerja unit PKBL.

2. Prinsip Konsistensi (Consistency)

Prinsip ini menuntut bahwa peristiwa ekonomi yang serupa seharusnya dicatat dan dilaporkan secara konsisten dari periode ke periode. Hal ini akan berimplikasi bahwa perlakuan akuntansi yang sama akan diterapkan untuk pos atau transaksi yang sama di masa datang. Tetapi, hal ini tidak menghalangin Unit PKBL menerapkan perlakuan akuntansi yang berbeda selama sesuai dengan SAK dan dapat menghasilkan informasi keuangan yang lebih relevan.

3. Prinsip Pengungkapan Lengkap (Full Disclosure)

Pengungkapan penuh menyaratkan bahwa Laporan Keuangan dirancang dan dibuat untuk menggambarkan secara wajar dan tidak menyesatkan atas peristiwa ekonomi yang telah mempengaruhi Unit PKBL untuk suatu periode sehingga laporan keuangan berguna bagi pemakainya. Semua informasi dalam laporan keuangan telah diungkapkan dengan lengkap dan benar serta tidak mengandung atau menghilangkan informasi material yang tidak benar.

4. Prinsip Penyajian Wajar (Fair Presentation)

Prinsip ini menekankan bahwa Laporan Keuangan hendaknya menyajikan secara wajar posisi keuangan, kinerja aktivitas, dan arus kas Unit PKBL. Telah dijelaskan sebelumnya bahwa PT. Angkasa Pura I (Persero) merupakan salah satu perseroan yang juga merupakan Badan Usaha Miliki Negera (BUMN). Sehingga pada prakteknya, PT. Angkasa Pura I (Persero) harus menerapkan salah satu program yang telah diatur dalam Peraturan Menteri No. 05/MBU/2007. Peraturan ini mengatur terkait tanggung jawab sosial BUMN di Indonesia yakni berupa Program Kemitraan dan Bina Lingkungan. Seperti yang terlah disebutkan dalam Peraturan Menteri tersebut bahwa maksud dan tujuan pendirian BUMN tidak hanya untuk mengejar keuntungan melainkan turut akitf untuk memberikan bimbingan dan bantuan kepada pengusaha golongan ekonomi lemah, koprasi dan masyarakat.

Ditinjau dari sudut pandang standar yang digunakan dalam penyusunan Laporan Program Kemitraan dan Bina Lingkungan untuk BUMN, yakni SAK ETAP dan PSAK 45, hal ini sesuai dengan maksud dan tujuan pendirian BUMN yang telah disebutkan dalam Peraturan Menteri No. 05/MBU/2007 yaitu tidak hanya untuk mengejar keuntungan. Sehingga telah tepat bila menggunakan PSAK 45 tentang Pelaporan Keuangan Entitas Nirlaba. Dalam PSAK 45 (revisi 2011) telah disebutkan bahwa ruang lingkup penerapan PSAK 45 adalah oleh lembaga pemerintah, dan unit-unit sejenis lainnya, sehingga PT. Angkasa Pura I (Persero) dalam hal ini dilihat dari sudut pandang BUMN memanglah harus menggunakan standar ini.

Komponen laporan keuangan yang digunakan dalam pedoman tersebut berbasis pada PSAK 45 (revisi 2011) paragraf 9 sebagaimana disebutkan bahwa, "Laporan keuangan entitas nirlaba meliputi laporan posisi keuangan (neraca) pada akhir periode laporan, 
laporan aktivitas serta laporan arus kas untuk suatu periode pelaporan, dan catatan atas laporan keuangan".

Laporan Program Kemitraan dan Bina Lingkungan ini disusun terpisah dari Laporan Keuangan Utama Perusahaan. Hal ini senada dengan pernyataan Bapak. Edwin Noya selaku PTS CSR Section Head PT. Angkasa Pura I (Persero) Cabang Bandar Udara International Sam Ratulangi Manado yang mengatakan, "Laporan PKBL dibuat terpisah dari laporan keuangan perusahaan, standar yang dipakai juga berbeda. Untuk PKBL dasarnya Peraturan Menteri menggunakan SAK ETAP dan PSAK 45 untuk entitas nirlaba, karena Program Kemitraan dan Bina Lingkungan (PKBL) merupakan suatu bentuk perwujudan kepatuhan dari PT. Angkasa Pura I (Persero) sebagai BUMN dalam menerapkan regulasi yang mengaturnya untuk melakukan tanggung jawab sosial.

Format pelaporan yang ditentukan dalam Surat Edaran Menteri BUMN No. SE02/MBU/Wk/2012 tentang Penetapan Pedoman Akuntansi Program Kemitraan dan Bina Lingkungan (PKBL) dengan format pelaporan yang dilakukan oleh PT. Angkasa Pura I (Persero) tidak terdapat perbedaan yang signifikan pada laporan posisi keuangan dan laporan aktivitas yang dibuat oleh PT. Angkasa Pura I (Persero) dikarenakan PT. Angkasa Pura I (Persero) memang mengacu pada pedoman akuntansi tersebut, sehingga perlakuan akuntansi (pengakuan, pengukuran, penyajian, dan pengungkapan) didasari oleh pedoman akuntansi tersebut.

\subsubsection{Laporan Keuangan PT. Angkasa Pura I (Persero)}

Berdasarkan hasil observasi komponen tanggung jawab sosial PT. Angkasa Pura I (Persero) diketahui terdapat dalam pos akun Beban ComDev (Community Development) pada Laporan Laba Rugi. Dari hasil wawancara dengan SPV (supervisor) CSR PT. Angkasa Pura I (Persero) Cabang Bandar Udara Internasional Sam Ratulangi, komponen ComDev merupakan program tanggung jawab PT. Angkasa Pura I (Persero) itu sendiri.

Seperti yang telah dijelaskan sebelumnya bahwa PT. Angkasa Pura I (Persero) merupakan salah satu BUMN yang berbentuk Perseroan Terbatas. Sehingga dalam tanggung jawab sosialnya mengacu pada dua hal yaitu Undang-Undang No. 40 tahun 2007 tentang Perseroan Terbatas dan Undang-Undang No. 19 tahun 2003 tentang Badan Usaha Milik Negara. Sebagai Perseroan Terbatas, PT. Angkasa Pura I (Persero) dituntut untuk melakukan tanggung jawab sosial dengan mengelola biaya sosialnya serta menyajikan dan mengungkapkan hasil kegiatan sosialnya. Begitu pula halnya dengan posisi PT. Angkasa Pura I (Persero) sebagai BUMN dimana harus memenuhi regulasi untuk menjalankan Program Kemitraan dan Bina Lingkungan sebagai bentuk tanggung jawab sosialnya. Sehingga bentuk perlakuan masing-masing tanggung jawab sosial tersebut berbeda.

Berdasarkan hasil wawancara dengan SPV (supervisor) CSR PT. Angkasa Pura I (Persero) Cabang Bandar Udara Internasional Sam Ratulangi diperoleh informasi bahwa untuk Program Kemitraan dan Bina Lingkungan (PKBL), dibuat Laporan Posisi Keuangan PKBL dan Laporan Aktivitas yang terpisah dari Laporan Posisi Keuangan utama Perusahaan. Sedangkan untuk program Corporate Social Responsibility (CSR) sendiri tercantum pada Laporan Laba Rugi dalam Pos Community Development (ComDev). SPV (supervisor) CSR PT. Angkasa Pura I (Persero), Bapak Indra saat wawancara mengemukakan bahwa Community Development merupakan suatu pos beban dalam Laporan Laba Rugi PT. Angkasa Pura I (Persero) yang menunjukkan beban yang dikeluarkan perusahaan untuk Program Tanggung Jawab Sosialnya (CSR).

Bapak Indra (supervisor CSR PT. Angkasa Pura I (Persero) dalam wawancara menyebutkan Beban ComDev dalam Laporan Laba Rugi digolongkan pada Pos Beban LainLain. Hal ini dikarenakan Program Tanggung Jawab Sosial merupakan program di luar operasional Perusahaan. Program Tanggung Jawab Sosial pada PT. Angkasa Pura I (Persero) dikelola oleh Kantor di masing-masing Provinsi. Hal ini dilakukan untuk memicu kinerja 
masing-masing area dan unit untuk menyusun program sebaik mungkin guna meningkatkan kualitas perseroan atau citra perseroan di mata masyarakat yang akan mampu mempermudah operasi perusahaan ke depannya.

\subsection{Pembahasan}

Berdasarkan tabel hasil penelitian tentang perlakuan akuntansi dan pelaporan pertanggungjawaban sosial di PT. Angkasa Pura I (Persero), dalam hal melaporkan tanggung jawab sosial sesuai dengan Undang-Undang No. 40 tahun 2007 - Perseroan Terbatas pasal 74 tentang Tanggung Jawab Sosial dan Lingkungan, PT. Angkasa Pura I (Persero) Cabang Bandar Udara Internasional Sam Ratulangi Manado telah sesuai karena mengolah tanggung jawab sosial berupa laporan Kemitraan dan Bina Lingkungan dan telah dituangkan dalam Laporan Posisi Keuangan dan Laporan Aktivitas, dan Laporan Keuangan Utama Perusahaan.

Dalam menaati Peraturan Menteri BUMN No. 5/MBU/2007 tentang Program Kemitraan dan Bina Lingkungan PT. Angkasa Pura I (Persero) Cabang Bandar Udara Internasional Sam Ratulangi Manado telah sesuai karena adanya prosedur pelaksanaan Program Kemitraan berupa membuat dan menyerahkan surat permohonan pinjaman (proposal) dengan format yang telah ditentukan PT. Angkasa Pura I (Persero), Menyeleksi persyaratan administrasi proposal, Membuat berita acara hasil rapat penetapan calon Mitra Binaan. Selanjutnya pengusulan calon Mitra Binaan berserta besaran nilai pinjaman kepada President Director dengan dilengkapi Pakta Integrasi yang ditandatangani oleh Kantor Pusat dan Kantor Cabang, Penyerahan dana Pinjaman. Jika pinjaman batal disalurkan maka dana tersebut dikembalikan ke rekening Kantor Pusat, Monitoring Usaha Mitra Binaan. Serta penyaluran Program Bina Lingkungan yang dilakukan berupa program pemberdayaan kondisi sosial masyarakat yang diutamakan berada di Daerah Lingkungan Kerja (DLKR) bandar udara, diantaranya program pendidikan, pelatihan dan pemagangan, membangun desa secara fisik maupun fasilitas.

Dalam menyajikan laporan mengenai tanggung jawab sosial diluar laporan keuangan seperti yang disebutkan dalam PSAK. No. 1 Paragraf 12 Revisi 2009 PT. Angkasa Pura I (Persero) Cabang Bandar Udara Internasional Sam Ratulangi Manado telah sesuai, yang meliputi asset, liabilitas, ekuitas, pendapatan dan beban serta laporan keberlanjutan. Sebelumnya telah disebutkan bahwa dalam PSAK. No 1 Paragraf 12 Revisi 2009 telah mengatur bahwa suatu entitas dapat pula menyajikan laporan mengenai lingkungan hidup dan laporan nilai tambah yang terpisah dari laporan keuangan utama. Oleh karena itu apabila diperlukan adanya aktivitas lain, suatu perusahaan dapat membuat laporan lain mengenai kegiatan tersebut di luar laporan keuangan utamanya, seperti laporan keberlanjutan (sustainability report).

PT. Angkasa Pura I (Persero) juga telah membuat dan menerbitkan Sustainability Report tersebut, namun laporan tersebut tidak dibuat oleh tiap-tiap unit. Laporan keberlanjutan ini disusun oleh kantor pusat PT. Angkasa Pura I (Persero) di Jakarta. Laporan tersebut telah mengacu pada GRI dimana telah memenuhi semua indikator unsur pelaporan. Apabila dilihat dari sudut pandang batasan pelaporan, informasi tanggung jawab sosial perusahaan dalam keberlanjutan PT. Angkasa Pura I (Persero) dilaporkan dalam bentuk narasi, karena memang tanggungjawab sosial tersebut tidak memiliki kendali terhadap perusahaan dan memang posisinya berada diluar opersional perusahaan. Dasar penyusunan Sustainability Report PT. Angkasa Pura I (Persero) tahun 2015 sendiri adalah seusai dengan aturan GRI (Global Reporting Initiative) - G4. 


\section{PENUTUP}

\subsection{Kesimpulan}

Berdasarkan hasil penelitian dan pembahasan yang telah dikemukakan sebelumnya, maka dapat diambil kesimpulan sebagai berikut.

1. PT. Angkasa Pura (Persero) I ini telah melaksanakan tanggung jawab sosial perusahaan dalam bentuk laporan posisi keuangan, aktivitas sosial perusahaan, dan laporan keuangan utama perusahaan yang dituangkan secara terpisah dalam bentuk Program Kemitraan Dan Bina Lingkungan.

2. Bentuk aktivitas sosial PT. Angkasa Pura (Persero) I sudah sesuai dengan peraturan menteri Negara BUMN nomor 05/MBU/2007 yaitu program CSR (Corporate Sosial Responsibilty) diterapkan dalam bentuk PKBL yang terbagi menjadi dua aktivitas yaitu program Kemitraan dan program Bina Lingkungan. Sedangkan untuk Penerapan Akuntansi Pertanggungjawaban Sosial pada PT. Angkasa Pura (Persero) I telah optimal dan sesuai dengan peraturan menteri Negara BUMN nomor 05/MBU/2007.

Untuk penerapan program CSR (Corporate Social Responsibility) PT. Angkasa Pura (Persero) I telah mematuhi bentuk kepatuhan perseroan dalam memenuhi UU No. 40 tahun 2007 tentang perseroan terbatas untuk melaksanakan tanggung jawab sosial. Dilaksanakan tanggung jawab sosial PT. Angkasa Pura (Persero) I terlihat pada laporan laba-rugi yang digolongkan pada bagian beban lain-lain dan pos beban itu di sebut ComDev (Community Development). Diakui beban karena dianggap tidak memiliki nilai ekonomis kedepannya dan merupakan pengeluaran diluar operasi utama perusahaan, sehingga murni untuk program tanggung jawab sosialnya. PT. Angkasa Pura I (Persero) telah menyajikan laporan mengenai tanggungjawab sosial diluar laporan keuangan utama perusahaan berupa laporan keberlanjutan sesuai dengan PSAK No. 1 Paragraf 12 Revisi 2009.

\subsection{Saran}

Berdasarkan kesimpulan yang diperoleh, maka penulis memberikan beberapa saran sebagai berikut.

1. Disarankan agar perusahaan tetap membuat laporan terpisah mengenai realisasi kegiatan agar lebih mudah mengevaluasi program yang berjalan serta berguna untuk mempertimbangkan program yang akan dilaksanakan.

2. Dikarenakan belum ada standar buku yang mengatur tentang pelaporan tanggung jawab sosial bagi perusahaan, disarankan untuk penelitian selanjutnya tetap menggunakan objek perusahaan Badan Usaha Milik Negara (BUMN) atas pertimbangan bahwa sebagai BUMN tentu harus mengikuti pedoman yang telah ditetapkan pemerintah, yang menjadi berbeda hanya bagaimana kebijakan perlakuan akuntansi untuk biaya sosial dari sudut pandang sebagai perseroan, dimana hal tersebut berdasar pada jenis kegiatan industri, teknologi dan kebijakan perusahaan.

\section{DAFTAR PUSTAKA}

Bayoud, 2012. An Empirical Study of The Relationship Between Corporate Social Responsibility Disclosure and Organizational Performance: Evidence From Libya. International Journal of Management and Marketing Research. Vol. 5, No. 3

Homayoun, 2015. Corporate Social Responsibility And It's Relevance To Accounting. Journal of Sustainable Development; Vol. 8, No. 9

Abdala, 2014. Social and Environmental Accounting Research: The Way Forward. International Journal of Economics and Management 8 (2): 365-383.

Ayu, 2014. Moderasi Corporate Social Responsibility Terhada $p$ Pengaruh Kinerja Keuangan Pada Nilai Perusahaan. Jurnal Akuntansi Udayana. Vol. 8, No. 2.

Ghofur, 2016. Perlakuan Akuntansi dan Pelaporan Pertanggungjawaban Sosial Perusahaan PT. PLN (Persero) P3BJB APP Surabaya. Jurnal Penelitian Ekonomi dan Akuntansi. Vol. 1, No. 1 
Global Reporting Initiative, 2016

Inghvi, N. M, Bodhanwala, 2012. Management Accounting: Text and Cases. Second Edition, Delhi: PHI Learning Private Limited

Peraturan Menteri BUMN No.5/MBU/2007 tentang Program Kemitraan dan Bina Lingkungan

PSAK 01. Penyajian Laporan Keuangan (Revisi 2009).

PSAK 45. Pelaporan Keuangan Entitas Nirlaba (Revisi 2010).

Sri, Urip, 2014. Strategi CSR: Tanggung Jawab Sosial Perusahaan Untuk Peningkatan Daya Saingan Perusahaan di Pasar Negara Berkembang. Tangerang Selatan: Lentera Hati.

Suwardjono, 2013. Teori Akuntansi Perekayasaan Pelaporan Keuangan. Yogyakarta BPFE.

Susanto, 2013. Pengaruh Pengungkapan Sustainability Report Terhadap Profitabilitas Perusahaan. Bussiness Accounting Review. Vol. 1 